\title{
触 New Disease Reports \\ First report of natural infection of Mungbean yellow mosaic India virus in two wild species of Vigna
}

\author{
Naimuddin $^{1}$, Mohd. Akram ${ }^{1}$ and Aditya Pratap ${ }^{2}$ \\ ${ }^{1}$ Division of Crop Protection, Indian Institute of Pulses Research, Kanpur 208024, India ; ${ }^{2}$ Division of Crop Improvement, \\ Indian Institute of Pulses Research, Kanpur 208024, India
}

*E-mail: naimk@rediffmail.com

Received: 24 Dec 2010. Published: 19 Apr 2011. Keywords: Vigna hainiana, Vigna trilobata, begomovirus

A number of wild relatives of the two cultivated species of Vigna ( $V$. mungo and $V$. radiata) are known to occur in different parts of India and are exploited for their useful genes, including resistance to yellow mosaic disease (YMD). There are publications on the characterisation and use of wild accessions of Vigna spp. that refer to resistance to YMD in some (Singh, 2004; Bisht et al., 2005) without identifying the causal virus involved. Since three distinct viruses (Mungbean yellow mosaic India virus, Mungbean yellow mosaic virus and Horsegram yellow mosaic virus) are reported to cause YMD in cultivated species of Vigna (Malathi \& John, 2008), proper identification of the yellow mosaic-causing virus is important. We report here natural infection with Mungbean yellow mosaic India virus, a begomovirus, as the causal agent of YMD of two wild Vigna species, $V$. hainiana and $V$. trilobata.

During the rainy season of 2010, accessions of wild species of Vigna hainiana (IC-331615, National Bureau of Plant Genetic Ressources, New Delhi, India) and V. trilobata (IC-331436), grown at Indian Institute of Pulses Research, Kanpur, India, showed symptoms like yellowing of inter-veinal tissue and bright yellow spots in the leaves (Fig. 1a, b). All plants of $V$. hainiana (8 plants) and $V$. trilobata (15 plants) were affected. The disease severity measured in terms of percentage foliage yellowing was $80 \%$ in the former and 30\% in the latter. Whiteflies (Bemisia tabaci) were also noticed feeding on plants of these accessions. Type of symptoms and presence of whitefly led us to suspect the involvement of a begomovirus. The association of a begomovirus was confirmed by PCR using primer pairs specific to MYMIV and MYMV (see Fig. 4 for details) that commonly infect cultivated species of Vigna in different parts of India (Karthikeyan et al., 2004; Usharani et al., 2004). Rolling circle amplification (RCA) was performed using REPLI-g ${ }^{\circledR}$ Mini Kit (Cat. No. 150023, Qiagen, USA) as per manufacturer's instructions and restriction digestion was also carried out to further confirm the presence of DNA A and DNA B of MYMIV.

Total DNA extracted from infected samples using a Qiagen DNeasy Plant Mini Kit was used as template in PCR and for RCA. In PCR, all the four samples drawn from each of the two accessions showing yellow mosaic symptoms gave positive results with MYMIV specific primer pairs NM1/NM2 and MYMIV-MPF/ MYMIV- MPR and yielded amplicons of $\sim 1000$ bp and $\sim 900$ bp respectively (Fig. 2a, b), indicating presence of both DNA A and DNA B components. Results with MYMV specific primers

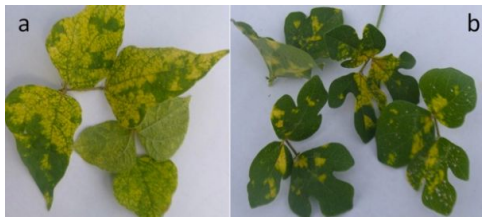

Figure 1

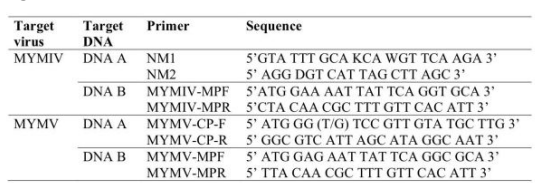

were negative. RCA products were subjected to restriction digestion using unique restriction enzymes $E c o$ RV (specific for DNA A) and $B g l$ I (specific for DNA B) of MYMIV. Digested products were subjected to agarose gel electrophoresis which revealed the presence of $\sim 2.7 \mathrm{~kb}$ DNA bands, further confirming the presence of MYMIV with both DNA A and DNA B components (Fig. 3). To the best of our knowledge, this is the first report of MYMIV infecting $V$. hainiana and $V$. trilobata.

\section{Acknowledgements}

The authors thank Dr. N. Nadarajan, Director, Indian Institute of Pulses Research, Kanpur for providing necessary facilities.

\section{References}

Bisht IS, Bhat KV, Lakhanpaul S, Latha M, Jayan PK, Biswas BK, Singh AK, 2005. Diversity and genetic resources of wild Vigna species in India. Genetic Resources and Crop Evolution 52, 53-68. [doi:10.1007/s10722-005-0286-0]

Karthikeyan AS, Vanitharani R, Balaji V, Anuradha S,

Thillaichidambaram P, Shivaprasad PV, Parameswari C, Balamani V, Saminathan M, Veluthambi K, 2004. Analysis of an isolate of Mungbean yellow mosaic virus (MYMV) with a highly variable DNA B component.Archives of Virology 149, 1643-1652. [doi:10.1007/s00705-004-0313-z]

Malathi VG, John P, 2008. Geminiviruses infecting legumes. In: Rao GP, Lava Kumar P, Holguin-Pena RJ, eds. Characterization diagnosis and management of plant viruses. Volume 3: vegetables and pulses crops. Houston, TX, USA: Studium Press LLC, 97-123.

Singh DP, 1994. Breeding for resistance to diseases in mungbean: Problems and prospects. In: Asthana AN and Kim DH, eds. Recent Advances in Mungbean Research. Kanpur, India: Indian Society of Pulses Research (IIPR), 152-164

Usharani KS, Surendranath B, Haq QMR, Malathi VG, 2004. Yellow mosaic virus infecting soybean in Northern India is distinct from the species infecting soybean in southern and western India. Current Science 86, 845-850.

Figure 4

To cite this report: Naimuddin, Akram M, Pratap A, 2011. First report of natural infection of Mungbean yellow mosaic India virus in two wild species of Vigna. New Disease Reports 23, 21. [doi:10.5197/].2044-0588.2011.023.021]

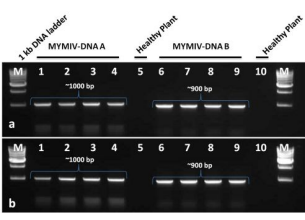

Figure 2

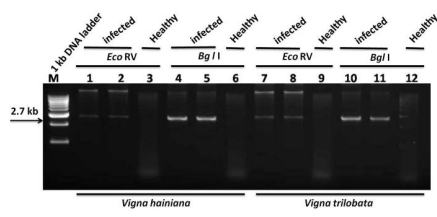

Figure 3 